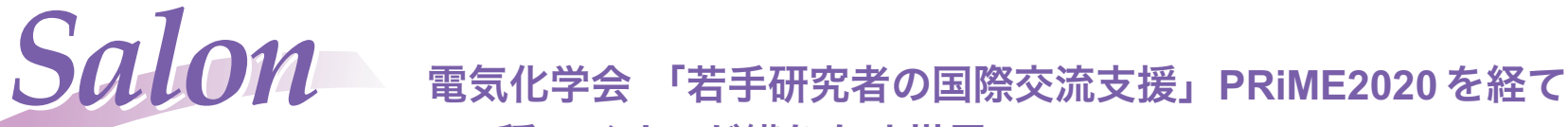 -2 種のイオンが織りなす世界— \\ 高出力・高エネルギー密度型 $\mathrm{Li}_{4} \mathrm{Ti}_{5} \mathrm{O}_{12} / / \mathrm{AC}$ ハイブリッド キャパシタに向けたデュアルカチオン電解液の開発
}

\section{近岡 優（東京農工大学大学院）}

この度 2020 年度電気化学会「若手研究者の国際交流支 援」の助成を受け，2020 年 10 月 4 日-10月 9 日にオンラ インにて開催された「PRiME 2020」に参加しました。

私は “A03 - Fast Energy Storage Processes and Devices Capacitors, Supercapacitors, and Fast-Charging Batteries" の セッションにて “Dual-Cation Electrolyte System Using Quaternary Ammonium Salts and Ionic Liquid for High Power and High Energy $\mathrm{Li}_{4} \mathrm{Ti}_{5} \mathrm{O}_{12} / / \mathrm{AC}$ Hybrid Capacitor System" と いうタイトルで発表しました。内容は高エネルギー密度 型ハイブリッドキャパシタに向けた新規高出力電解液の 開発です。背景として， $\mathrm{Li}^{+}$電池などの蓄電デバイスの高 エネルギー密度化に向け，近年では活物質材料の研究だ けでなく電極の厚膜化が有効な手法として注目されてい ます。しかし， $100 \mu \mathrm{m}$ を超える厚膜電極では電極内のイ オン抵抗が支配的な抵抗因子となり，イオン伝導性の低 下に伴って出力特性が顕著に低下するという課題があり ました。これに対し私は蓄電デバイスの反応素過程を考 えた際，反応イオン種が関与するのが電極/電解液界面の 反応のみであることに基づき，電解液バルクや電極内の イオン拡散を異種イオンが担うことで従来系を超える高 いイオン伝導度と高出力化を達成する電解液が構築可能 であると考えました。そこで本研究では高解離度と高拡 散性を有する 4 級アンモニウム塩 $\mathrm{SBPBF}_{4}$ やイオン液体 $\mathrm{EMIBF}_{4}$ に着目し，これらを異種イオンとして混合した デュアルカチオン電解液を開発しました。本研究では, このデュアルカチオン電解液を電極厚み $600 \mu \mathrm{m}$ の $\mathrm{Li}_{4} \mathrm{Ti}_{5} \mathrm{O}_{12} / /$ Activate Carbonハイブリッドキャパシ夕に適用 し, 電極内のイオン輸送高速化と出力特性向上に対する 有効性を明らかにしました。本研究の特色は，これまで の電解液設計で注目されていた「反応イオン種の輸送能 向上」ではなく，それらが低下した場合においても「支 持電解質による系全体のイオン伝導度向上」が高出力化 に有効であることを種々の支持電解質を用いた系で実証 した点です。また, 出力特性向上のメカニズム解析にお いて, 高速化要因を反応素過程ごとに分割し, 多孔質電 極内のイオン拡散と電極/電解液界面での反応性向上が高 出力化の要因であることを明らかにしました(Y. Chikaoka,

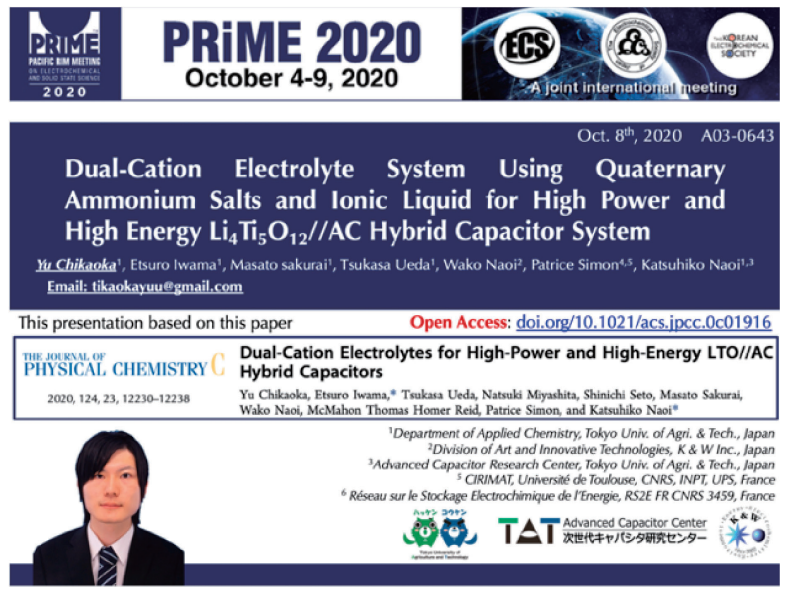

オンラインプレゼンテーションでの表紙.

E. Iwama, K. Naoi et al., J. Phys. Chem. C, 124(2020), 12230.). さらに, デュアルカチオン電解液では出力特性向上だけ でなく, 電極/電解液界面での副反応抑制による耐電圧特 性向上と水素ガス発生抑制も達成しています (Y. Chikaoka, E. Iwama, K. Naoi et al., Electrochim. Acta, 368(2021), 137619.)。この研究は $\mathrm{Li}^{+}$をベースとした電解液設計だけ でなく, $\mathrm{Na}^{+} \cdot \mathrm{K}^{+} \cdot \mathrm{Mg}^{2+}$ 電池等への応用も期待でき, 更 なる研究の発展を目指していきたいと思います.

本大会は私自身初となる動画プレゼンテーションの作 成となり, 何度も練習と撮影を繰り返して発表に臨みま した。オンライン発表では従来の形式と異なり, 現地で の交流やディスカッションができなかった点が残念でし た。しかし，タイムテーブルに囚わ扎ずに他の研究発表 を聴講できた点や何度も発表を見直せた点, チャット ボックスで気軽に質問できた点がオンライン開催ならで はの魅力として感じました。今回の発表を経て, 動画プ レゼンテーションの経験や他の研究内容を今後の研究者 生活に活かしながら, より良い研究と発表ができる研究 者を目指してこれまで以上に精進したいと感じました。

最後になりましたが，今回の PRiME2020の参加に際し， 助成を頂きました電気化学会および関係者の方々にこの 場をお借りして心より御礼を申し上げます。 